DOI: https://doi.org/10.32839/2304-5809/2021-11-99-53

уДК $81 ` 33$

Романишин Н.І., Маковяк Я.В.

Національний університет «Львівська політехніка»

\title{
ДОСЛІДЖЕННЯ МЕТАФОР НА ОСНОВІ ЧАСТОТНОЇ ЛЕКСИКИ У ТВОРАХ Д.Г. ЛОУРЕНСА
}

\begin{abstract}
Анотація. У статті проаналізовано ідіостиль класика англійської літератури Девіда Герберта Лоуренса. Матеріалом для аналізу послужили кілька творів: роман "The Rainbow", а також оповідання "The Woman Who Rode Away", "Sun". "Smile", "Odour of Chrysanthemums", "The Prussian Officer". Вперше використано корпусне дослідження частотної лексики ідіостилю Д.Г. Лоуренса з використанням програми частотного та контент аналізу AntConc для пошуку та аналізу метафори. Обсяг проаналізованих лексичних одиниць становив 196661 слововживання. В ході дослідження було виявлено метафори з колоративами, з частотною лексикою на тему ПРИРОДА, метафори, що виражають душевний стан, емоційний стан та інтелектуальний стану людини. Варто відзначити, що метафори Д.Г. Лоуренса працюють на розвиненого читача, що володіе високим рівнем розвитку здатності до рефлексії та розподілу смислів.
\end{abstract}

Ключові слова: ідіостиль, модерніст, частотна лексика, метафора, колоратив.

Romanyshyn Natalia, Makoviak Yana

Lviv Polytechnic National University

\section{STUDY OF METAPHORS BASED ON FREQUENCY VOCABULARY IN THE NOVELS OF D.H. LAWRENCE}

Summary. The article analyzes the idiostyle of the classic English literature David Herbert Lawrence. Creativity D.H. Lawrence has long attracted the attention of researchers who seek to explain his idiosyncrasy, analyzing both the lexical and semantic features of his texts and the factors of life and work of the English modernist writer. The novelty of the work lies in the study of metaphor based on the identification of frequency vocabulary in the texts of D.H. Lawrence as one of the most famous English authors of the XX century. The main purpose of this work is to study and identify and study metaphors based on the frequency vocabulary of the studied works of D.H. Lawrence. The material for the analysis was several works: the novel "The Rainbow", as well as the story "The Woman Who Rode Away", "Sun". "Smile", "Odor of Chrysanthemums", "The Prussian Officer". For the first time, the corpus research of frequency vocabulary of idiostyle D.H. Lawrence was used. The volume of analyzed lexical units was 196,661 word usages. The study revealed metaphors with colorants, with frequency vocabulary on the topic of NATURE, metaphors that express the mental state, emotional state, and intellectual state of man. The nature of metaphors and, in general, metaphorization of images is dictated primarily by the attitude of D.H. Lawrence to reveal the inner world, feelings, and emotions of the characters. As we can see, the article reveals that colorants are frequent vocabulary in the texts of D.G. Lawrence. The paper presents the frequency analysis of the studied colorants and determines that the most frequent coloronym found in metaphors is - white (25\%). This property of the author's idiostyle, regardless of the theme of the work and the formulation of social or philosophical tasks in it, is present in the idiostyle of D.H. Lawrence and is an important organizational factor in his work. Through the disclosure of the subtlest shades of emotions, spontaneity, and dynamics of feelings and instincts D.H. Lawrence shows a person from the inside, exposing his unconscious motives and desires. It is worth noting that the metaphors of D.H. Lawrence work for a developed reader who has a high level of development of the ability to reflect and distribute meanings.

Keywords: idiostyle, modernist, frequency vocabulary, metaphor, coloronym.

$\Pi$ остановка проблеми. Сучасний етап вивчення ідіостилю письменника характеризуеться включенням широкого спектру понять та елементів його структури, насамперед параметрів авторської самосвідомості та самовираження, що підтверджують дослідження індивідуального стилю в рамках психолінгвістичного та лінгвокогнітивних підходів [4].

Число таких досліджень зростає, проте, кількість досліджень саме ідіостилю Д.Г. Лоуренса $€$ дуже мало. Варто відзначити, що до компонентів ідіостилю відносять такі стилістичні засоби: метафори, порівняння, гіперболи, епітети тощо.

Метафора є одним із найпоширеніших тропів. Інколи цим словом навітъ характеризують образну мову взагалі, говорячи про метафорику мови, художню мову як метафоричну тощо. В художній мові метафора сприймається активно і виконуе естетичну функцію; там вона - явище образного мислення, бо збуджуе уявлення і збагачує уяву, розкриваючи способом зіставлення предмета $з$ іншим, незвичайним, новим, нові сторони явища чи предмета; вона надає сприйманням емоційного забарвлення. Оскільки Д.Г. Лоуренс використовує яскраві метафори у своїх творах, то залишаеться актуальним питання їх дослідження на основі виявлення частотної лексики.

Аналіз останніх досліджень і публікацій. Останнім часом все більша увага в лінгвістиці приділяеться особливостям індивідуального стилю, що виявляеться у текстах на різних мовних рівнях. Вивченню синтаксичних, морфологічних, словотвірних, лексичних, стилістичних ознак ідіостилю присвячено велику кількість досліджень (В. Григор'єв, Савищька Л., С. Срмоленко, Н. Сологуб, Л. Пустовіт, І. Бабій, А. Мойсієнко, Г. Жуковець, О. Кухар-Онишко, Д. Наливайко, С. Перепльотчикова, I. Смущинська, А. Ткаченко, О. Фоменко, А. Шайкевич, Н. Шмарова та ін.). 
Виділення не вирішених раніше частин загальної проблеми. У центрі уваги нашої роботи знаходиться художня система автора, яка отримала у сучасній лінгвістиці назву «ідіостиль». Виникнення цього поняття е закономірним наслідком багаторічного пошуку великої кількості видатних дослідників, які намагалися проаналізувати та зрозуміти природу словесної художньої творчості [1].

Творчість Д.Г. Лоуренса давно привертае увагу дослідників, які прагнуть пояснити його ідіостиль, аналізуючи як лексико-семантичні особливості його текстів, так і фактори життя та творчості англійського письменника-модерніста.

Новизна роботи полягає у дослідженні метафори на основі виявлення частотної лексики в текстах Д.Г. Лоуренса як одного 3 найбільш відомих англійських авторів XX століття. Аналіз лексичного компонента ідіостилю автора проводиться шляхом корпусного дослідження авторської частотної лексики (у "The Woman Who Rode Away", "The Odour of Chrysanthemums", "The Prussian Officer", "Sun", "Smile" ma "The Rainbow”), що охоплюе 196661 слововживання.

Мета статті. Головною метою цієї роботи є дослідження та виявлення та дослідження метафор на основі частотної лексики досліджуваних творів Д.Г. Лоуренса.

Виклад основного матеріалу. У статті аналізуються лексичні особливості ідіостилю класика англійської літератури Д.Г. Лоуренса. Як ілюстращію вживання лексичних засобів, що входять до структури ідіостилю автора, вибрано оповідання "The Woman Who Rode Away", "The Odour of Chrysanthemums", "The Prussian Officer", "Sun", "Smile" і роман "The Rainbow".

Характер метафор i, загалом, метафоризації образів диктуеться передусім установкою Д.Г. Лоуренса на розкриття внутрішнього світу, почуттів та емоцій персонажів. Ця властивість ідіостилю автора незалежно від теми твору та постановки у ньому соціальних чи філософських завдань присутня в ідіостилі Д.Г. Лоуренса і $е$ важливим організаційним чинником його творчості. Через розкриття найтонших відтінків емоцій, спонтанність і динаміку почуттів та інстинктів Д.Г. Лоуренс показуе людину зсередини, оголюе iï несвідомі мотиви та бажання [3].

Метафори Лоуренса працюють на розвиненого читача, що володіе високим рівнем розвитку здатності до рефлексії та розподілу смислів, тому що вони виходять за межі порівнянь реалій дійсності та апелюють до нашої свідомості та чуттевості. Наприклад, під час дослідження, було виявлено такі метафори:

1) Now she felt inside her quite another sort of power, something greater than herself, darker and more savage, the element flowing upon her. (Sun)

2) She was some mystical object to them, some vehicle of passions too remote for her to grasp. (The Woman Who Rode away)

3) The immense fundamental sadness, the grimness of ultimate decision, the fixity of re-venge, and the nascent exultance of those that are going to triumph - these things she could read in their faces... (The Woman Who Rode Away)

4) But now he saw them crouching under the sky, with still the dark, mysterious world of reality inside, but as a world within a world, a sort of side show, whereas before they had been as a world to him within a chaos: a reality, an order, an absolute, within a meaningless confusion. (The Raimbow)

5) Spanned round with rainbow, the jewelled gloom folded music upon silence, light upon darkness, fecundity upon death, as a seed folds leaf upon leaf and silence upon the root and the flower, hushing up the secrets of all between its parts, the death out of which it fell, the life into which it has dropped, the immorality it involves, and the death it will embrace again. (The Rainbow)

В описі зовнішнього, реального світу Д.Г. Лоуренс використовуе метафори - аналогії, наприклад:

1) ... his bare legs were glowing with a strange transfigured ruddiness in the powerful light, and his straw hat with its half-absurd decorations of flowers and feathers shining showily above his river of long black hair. (The Woman Who Rode Away);

2) In the great bay of railway lines, bulked with trucks, there was no trace of light, only away back she could see a few yellow lamps at the pittop, and the red smear of the burning pitbank on the night. (The Odour of Chrysanthemums);

3) On either hand, the valley, wide and shallow, glittered with heat; dark green patches of rye, pale young corn, fallow and meadow and black pine woods spread in a dull, hot diagram under a glistening sky. (The Prussian Officer).

У ході аналізу лексики у досліджуваних творах було використано також корпусне дослідження на частотність лексичних одиниць у всіх п'яти творах, а також аналіз на основі контексту. Сумарна кількість слововживання у п'яти оповіданнях складае слова (1877 слів - The Prussian Officer, 1870 слів - Odour of Chrysanthemums, 1824 слова - Sun, 655 слів - Smile, 2657 слів The Woman Who Rode Away,187814 слова The Rainbow).

Під час пошуку частотної лексики у конкордансі, спостерігаємо частотність метафоричних способів актуалізації концепту ПРИРОДА, наприклад: as easily as a full river, like a full river of life, to be like a flower in the garden, to be like a sun-stone, to thy peace be as a river, peace like a river, like the fag-end of the village, to be where heaven and earth are divided, to struggle as an animal, to rise from the brown stone into life, to be between heaven and earth, a heavy sky lies on the earth, heart heavy as the sodden earth, heaven and earth put together, like electricity in the earth, the sea of blood, the black sea of death, like a swimmer in a dark sea, like a fish in the sea та інші, що відображають антропоморфне сприйняття явищ природи та просторових понять.

Під час аналізу частотної лексики було виявлено багато метафор, метафоричних виразів. Наприклад,

- метафори, що виражають душевний стан: his soul sprang towards her too; her soul suddenly swept towards him; at the bottom of the soul; physical injustice burned to her soul; have no soul; cool water in my soul (див. таблицю 1);

- метафори для вираження емоційного стану - CTPAX: her heart sank to her shoes; his soul screamed with fear and agony; his fear burst like 
Таблиця 1

\begin{tabular}{|l|c|c|}
\hline \multirow{4}{*}{ ДУШЕВНИЙ СТАН } & heart+love & his heart melted suddenly for her; \\
\cline { 2 - 3 } & heart+love & her heart was full of love to him \\
\cline { 2 - 3 } & soul & his soul sprang towards her too \\
\cline { 2 - 3 } & soul & her soul suddenly swept towards him \\
\cline { 2 - 3 } & soul & her soul washed transparent \\
\cline { 2 - 3 } & soul & the soul does come up \\
\cline { 2 - 3 } & soul & the soul does come up, shoots like a kittiwake into the light \\
\hline
\end{tabular}

Таблиця 2

\begin{tabular}{|c|c|c|}
\hline \multirow{5}{*}{ CTPAX } & heart & her heart sank to her shoes \\
\hline & heart & her heart began to burn \\
\hline & heart & her heart melted in hot pain \\
\hline & heart & her heart stood still \\
\hline & heart & heart gave a little thrill \\
\hline \multirow{10}{*}{ КОХАННЯ } & heart & her heart began to sing \\
\hline & heart & his heart melted suddenly \\
\hline & love & The love in her fingertips caressed the leaves \\
\hline & love & For the bonds of love are ill to loose! \\
\hline & love & wave of hot love went over her \\
\hline & love & Love was God's gift \\
\hline & love & love laughs at sludge; \\
\hline & heart & love died \\
\hline & heart & his heart melted in fear from the fierce, beaked, harpy's kiss \\
\hline & love & his love turned back into her \\
\hline
\end{tabular}

Таблиця 3

\begin{tabular}{|c|c|c|}
\hline \multirow{4}{*}{$\begin{array}{c}\text { СНТЕЛЕКТУАЛЬНИЙ } \\
\text { СТАН }\end{array}$} & mind & mind can only analyse and rationalize \\
\cline { 2 - 3 } & mind & The logical mind pretends to rule the roost \\
\cline { 2 - 3 } & mind & time hind filling up with mist, with nothingness \\
\cline { 2 - 3 } & mind & His mind was clear and hard \\
\cline { 2 - 3 } & mind & His mind and hands were busy \\
\hline
\end{tabular}

a bubble surcharged; felt washed-out with fear; fear of the mining and iron;

- метафрори, які позначають ЛЮБОВ: his heart melted suddenly; The love in her fingertips caressed the leaves; For the bonds of love are ill to loose! wave of hot love went over her; Love was God's gift; love laughs at sludge; love died; his love turned back into her (див. таблицю 2);

- метафори на вираження інтелектуального стану: his mind filling with nothingness, with mist (див. таблицю 3).

Під час дослідження частотної лексики було виявлено використання великої кількості колоративів. Ми виокремили декілька окремих груп за основним компонентом, що є колоративом, а саме:

1) з колоративом red;

2) 3 основним колоративом orange та додатковим колоративом brown;

3) з основним колоративом yellow та додатковим колоративом golden;

4) з колоративом green;

5) з колоративом blue;

6) 3 колоративом black;

7) 3 колоративом white.

Як бачимо, колоративи є частотною лексикою у текстах Д.Г. Лоуренса (див. таблицю 4, рис. 1). На рис. 1 представлено частотний аналіз колоративів у досліджуваних текстах Д.Г. Лоуренса.
Таблиця 4

Кількість вживань колоративів у досліджуваних текстах Д.Г. Лоуренса

\begin{tabular}{|l|c|}
\hline \multicolumn{1}{|c|}{ Колоратив } & Кількість вживань у текстах \\
\hline White & 585 \\
\hline Black & 409 \\
\hline Blue & 310 \\
\hline Red & 244 \\
\hline Grey & 152 \\
\hline Yellow & 148 \\
\hline Brown & 134 \\
\hline Green & 133 \\
\hline Gold & 89 \\
\hline Pink & 64 \\
\hline Purple & 45 \\
\hline
\end{tabular}

Під час частотного аналізу колоративів було виявлено такі метафори: black for the funeral; blossom, my darling, blossom, be a rose of roses; the blood of the rose bush; The bright green apples full of disappointment; rosy cyclamen, ecstatic fore-runner; lilies in the fire, white and gold; rosy-muzzled violets; the dawn was apple-green; I (Lawrence) am like a rose; the buttercups was I (Ophelia) тощо.

Розглянемо використання та значення колоронімів у передачі базових емоційних концептів 


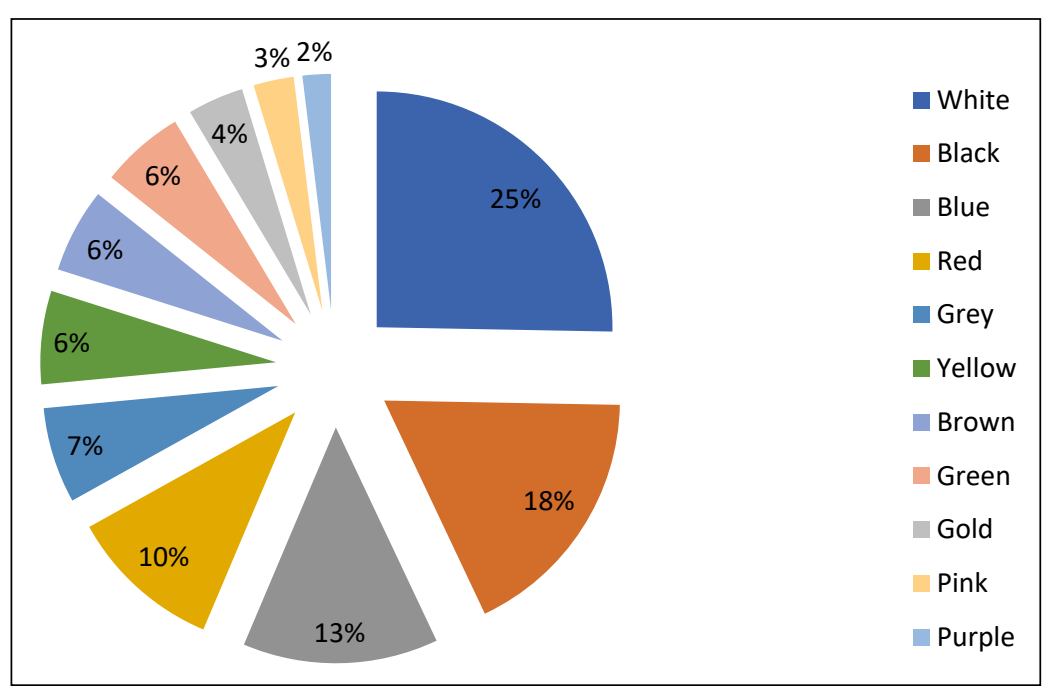

Рис. 1. Частотний аналіз вживання колоративів

у поезії Д.Г. Лоренса. У поле зору ряду сучасних теоретичних та прикладних досліджень потрапляе також проблема ролі позначень кольору у вираженні емоцій.
На основі когнітивних метафор ми виокремлюемо наступну чітко виражену опозицію у співвідношенні вербалізованих емоцій та кольорів. позитивне негативне. Наприклад, good is white; life is light. happiness is light; light in the eyes - for happiness; bad is black; death is darkness; death is night; sad is dark; emotion is light/dark; love is fire. anger is fire; blushing for love; redness in the face for anger [5].

Висновки і пропозиції. Проведений аналіз виявляе типові закономірності у використанні частотної лексики Д.Г. Лоуренсом, з допомогою якої можна досліджувати метафори, виявляти їх. Твори Д.Г. Лоуренса є найбагатшим матеріалом для вивчення метафор. У його творах природа, кольори та емощії часто фігурують як мовне втілення метафрор. Підсумовуючи роботу, ми можемо відмітити такі перспективи подальшого дослідження. На наш погляд було б цікаво дослідити особливості перекладу когнітивної метафори.

\section{Список літератури:}

1. Григорьев В.П. Грамматика идиостиля: В. Хлебников. Москва : Наука, 1983. 223 с.

2. Ссипенко Н.Г. Лексико-семантичні компоненти авторського стилю і мовна картина світу (на матеріалі англомовної прози воєнної та мирної тематик) : автореф. дис. на здобуття наук. ступеня канд. фрілол. наук : спец. 10.02.04 "Германські мови". Чернів. нац. ун-т ім. Ю. Федьковича. Чернівці, 2007. 20 с.

3. Крюкова Н.Ф. Системное описание средств метафоризации : учебное пособие [Текст]. Тверь : Твер. гос. ун-т, 2008. C. 98

4. Крюкова Н.Ф. Средства метафоризации и понимание текста : монография. Тверь : Твер. гос. ун-т, 1999. С. 127.

5. Стельмах Б. Індивідуальний стиль як об’єкт лінгвостилістичних досліджень. Вісник Улман. педуніверситеmy : зб. наук. пр. / голов. ред. В.Г. Кузь. Київ : Знання України, 2004. Серія : “Філологія (мовознавство)”. C. $228-233$

6. Burrows J.F. Computers and the Study of Literature/ J.F. Burrows // Computers and Written Texts. Oxford, 1992. P. 167-204.

7. Hoover D. L. Quantitative Analysis and Literary Studies. URL: http://digitalhu-manities.org3030/companion/ view?docId=blackwell/9781405148641/9781405148641.xml\&chunk.id=ss1-6-9\&toc.depth=1\&tocid=0\&brand= 97814051486 41_brand (дата звернення: 07.11.2021).

8. Lawrence D.H. Odour of Chrysanthemums and Other Stories. Москва : Прогресс, 1997. 296 c.

9. Lawrence D.H. The Rainbow. Москва : Радуга, 1985. 576 c.

10. Lawrence D.H. The Woman Who Rode Away and Other Stories. URL: http://gutenberg.net.au/ebooks04/ 0400301h.html (дата звернення: 07.11.2021).

\section{References:}

1. Grigor'ev V.P. (1983) Grammatika idiostilya: V. Khlebnikov. Moscow: Nauka, 223 p. (in Russian)

2. Yesypenko N.H. (2007) Leksyko-semantychni komponenty avtorskoho styliu i movna kartyna svitu (na materiali anhlomovnoi prozy voiennoi ta myrnoi tematyk): avtoref. dys. na zdobuttia nauk. stupenia kand. filol. nauk: spets. 10.02.04 "Hermanski movy". Cherniv. nats. un-t im. Yu. Fedkovycha. Chernivtsi, 20 p. (in Ukrainian)

3. Krjukova N.F. (2008) Sistemnoe opisanie sredstv metaforizacii: uchebnoe posobie. Tver': Tver. gos. un-t, p. 98. (in Russian)

4. Krjukova N.F. (1999) Sredstva metaforizacii i ponimanie teksta: monografija. Tver': Tver. gos. un-t, p. 127. (in Russian)

5. Stelmakh B. (2004) Indyvidualnyi styl yak obiekt linhvostylistychnykh doslidzhen. Visnyk Uman. peduniversytetu: zb. nauk. pr. / holov. red. V. H.Kuz. Kyiv: Znannia Ukrainy. Seriia: "Filolohiia (movoznavstvo)", pp. $228-233$. (in Ukrainian)

6. Burrows J.F. (1992) Computers and the Study of Literature. Computers and Written Texts. Oxford, pp. 167-204.

7. Hoover D. L. Quantitative Analysis and Literary Studies. Available at: http://digitalhu-manities.org3030/ companion/view?docId=blackwell/9781405148641/9781405148641.xml\&chunk.id=ss1-6-9\&toc.depth=1\&tocid= 0\&brand=9781405148641_brand (accessed 07 November 2021).

8. Lawrence D.H. (1997) Odour of Chrysanthemums and Other Stories. Moscow: Prohress, $296 \mathrm{p.}$

9. Lawrence D.H. (1985) The Rainbow. Moscow: Raduha, $576 \mathrm{p}$.

10. Lawrence D.H. The Woman Who Rode Away and Other Stories. Available at: http://gutenberg.net.au/ ebooks04/040 0301h.html (accessed 07 November 2021). 